\title{
KEMITRAAN SEBAGAI STRATEGI PENGEMBANGAN PARIWISATA DAN INDUSTRI HOSPITALITI
}

\author{
Oleh: \\ DARWIS \\ Politeknik Pariwisata Makassar, Jl. Gunung Rinjani, Metro Tanjung Bunga, Makassar \\ Email: darwiss40@yahoo.co.id \\ ILHAM JUNAID \\ Politeknik Pariwisata Makassar, Jl. Gunung Rinjani, Metro Tanjung Bunga, Makassar \\ Email: illank77@yahoo.co.id
}

Abstrak

Tujuan karya ilmiah ini adalah untuk menguraikan konsep kemitraan (partnership) dan kaitannya dengan pengembangan pariwisata dan industri hospitaliti. Pariwisata membutuhkan kerjasama berbagai pihak, tidak semata-mata menjadi tugas pemerintah atau industri pariwisata. Kemitraan menjadi suatu strategi dalam mempertemukan dan melibatkan para stakeholder pariwisata agar perencanaan dan implementasi kegiatan dapat berjalan sesuai dengan tujuan pariwisata yang berkelanjutan. Kemitraan diartikan sebagai serangkaian bentuk atau rencana (kegiatan) yang terstruktur dan berkesinambungan antara dua atau lebih pihak dimana keduanya saling mengidentifikasi, mendukung dan memenuhi kebutuhan satu sama lain. Kemitraan formal dan informal, terstruktur dan khusus adalah bentuk-bentuk kemitraan. Istilah kemitraan juga sering dikaitkan dengan kolaborasi atau kerjasama yang dapat ditunjukkan melalui kemitraan antar institusi, sektor publik dan swasta maupun antar destinasi dan daya tarik wisata. Mengingat kemitraan memberikan dampak positif terhadap pengembangan pariwisata dan industri hospitaliti, tulisan ini merekomendasikan pentingnya meningkatkan kemitraan antar lembaga dan melibatkan masyarakat (stakeholder) dalam perencanaan dan pengembangan pariwisata.

Kata kunci: kemitraan, kolaborasi, pengembangan pariwisata, industri hospitaliti, stakeholder pariwisata

\begin{abstract}
This paper aims at explaining the concept of partnership and its link to tourism development and the hospitality industry. Tourism development requires collaborative work among different stakeholders. Hence, partnership is considered a strategy in involving people to participate in planning and activities of tourism which then links to the goal of sustainable tourism. Partnership is a continuous and sustainable activity that involves two or more parties where they identify and support their needs for achieving targeted goals. Partnership is sometimes used interchangeably with collaboration. Nevertheless, the writers argue that they have the same meaning that may include partnership between institutions, public-private sector partnership and between destinations and tourism attractions. Due to the positive consequences of partnership, this paper suggests institutions and tourism stakeholders to improve partnership for developing tourism and the hospitality industry.
\end{abstract}

Keywords: partnership, collaboration, tourism development, hospitality industry, tourism stakeholders

Jurnal Kepariwisataan, Volume 10, No. 01 Februari 2016, Halaman 01 - 13 


\section{PENDAHULUAN}

Mayoritas negara di dunia meyakini bahwa sektor pariwisata memberikan kontribusi yang besar terhadap pertumbuhan ekonomi suatu negara. Indonesia termasuk negara berkembang yang menekankan pentingnya mengembangkan sektor pariwisata untuk mendongkrak perekonomian masyarakat (Dahles, 2000). Salah satu alasan dari upaya mengembangkan pariwisata adalah karena pariwisata mampu menjadi jembatan untuk penyediaan lapangan kerja bagi masyarakat. Masyarakat yang secara langsung bekerja di industri pariwisata (misalnya akomodasi, transportasi, jasa perjalanan, hiburan, dll.) maupun mereka yang secara tidak langsung mendapatkan manfaat positif pariwisata (Archer, Cooper, dan Ruhanen, 2005; Ardahaey, 2011; Wearing dan Neil, 2009), tentunya mengharapkan pariwisata semakin dikembangkan sebagai alternatif peningkatan kesejahteraan masyarakat. Pariwisata juga menjadi pendorong pelestarian sumber daya alam dan budaya di suatu destinasi.

Pengembangan pariwisata tidak terlepas dari industri atau usaha pariwisata yang terlibat dalam memberikan pelayanan jasa kepada wisatawan. Mengingat aktifitas pariwisata tidak hanya melibatkan satu aspek (misalnya hanya tugas pemerintah semata), maka pelayanan ke wisatawan ataupun kepuasan wisatawan yang berkunjung ke suatu destinasi tidak semata-mata tergantung pada satu peran stakeholder semata. Keterkaitan masyarakat dari berbagai kelompok menjadi penentu pengembangan pariwisata. Ini berarti bahwa stakeholder pariwisata memiliki kontribusi yang besar dalam mencapai tujuan pengembangan pariwisata (Caffyn, 2000; Getz dan Timur, 2005; Tuohino dan Konu, 2014).

Peran para stakeholder tersebut tidak dapat maksimal tanpa ditunjang dengan suatu langkah strategis yang dilakukan oleh pengelola suatu daya tarik wisata ataupun pihak yang memiliki otoritas pengelolaan pengembangan pariwisata. Kemitraan (partnership), suatu langkah atau strategi utama pengembangan suatu destinasi wisata. Dapat dibayangkan jika pariwisata yang sedang dikembangkan tidak menerapkan upaya atau langkah kemitraan dengan pihak-pihak terkait. Kemitraan ini bukanlah merupakan strategi baru ataupun pendekatan baru bagi mereka yang berkecimpung dalam dunia pariwisata. Kemitraan justru telah menjadi perhatian pemerintah, industri pariwisata ataupun praktisi pariwisata sejak pariwisata dikembangkan di Indonesia.

Kemitraan menjadi kata kunci jika suatu destinasi atau daya tarik wisata diperhadapkan pada persaingan menarik wisatawan untuk datang ke suatu destinasi. Fyall dan Garrod (2003) berpendapat bahwa persaingan dalam dunia usaha pariwisata serta pemberian pelayanan ke customer menjadi alasan pentingnya kemitraan untuk diterapkan. Selain itu, multiplier effect dari pariwisata yang di dalamnya melibatkan individu ataupun kelompok menjadikan strategi kemitraan penting 
untuk dipahami dan diimplementasikan.

Meskipun kemitraan disadari sebagai bagian yang tak terpisahkan dari pengembangan pariwisata, konsep kemitraan masih memerlukan penjabaran. Secara aplikatif, suatu organisasi ataupun kelompok telah melakukan upaya kemitraan. Namun, kajian pustaka dalam literatur Bahasa Indonesia yang mengeksplorasi kemitraan dan kaitannya dengan pariwisata dan hospitaliti masih terbatas. Penulis berpendapat bahwa perlu ada penjabaran secara mendalam mengenai konsep kemitraan dalam konteks pengembangan pariwisata dan hospitaliti dan bagaimana implementasinya secara nyata. Karena itu, tulisan ini merupakan kajian teoretis yang membahas kemitraan dalam perspektif pariwisata dan hospitaliti. Tujuan penulisan karya tulis ini adalah memberikan eksplanasi ataupun argumentasi mengenai konsep kemitraan.

\section{PEMBAHASAN}

\section{Defenisi Kemitraan dan Alasan Mengembangkan Kemitraan}

Perencanaan dan pengelolaan pariwisata di suatu destinasi tidak terlepas dari keterlibatan beberapa kelompok masyarakat (ataupun individu-individu) baik mereka yang terlibat secara langsung maupun tidak langsung. Mereka ini dapat dikategorikan sebagai stakeholder pariwisata. Mengingat adanya stakeholder ini, maka ada tuntutan untuk melibatkan mereka dalam perencanaan, penentuan kebijakan pengembangan hingga pada pengelolaan daya tarik wisata ataupun usaha pariwisata. Kemitraan muncul karena adanya keinginan untuk melibatkan mereka (stakeholder) dengan harapan bahwa pengalaman, pengetahuan, keterampilan serta suara mereka dapat terwakilkan dalam pengambilan kebijakan. Kemitraan memungkinkan mereka yang berada dalam kategori sektor publik, swasta maupun kelompok lainnya untuk terlibat dalam diskusi, negosiasi serta mengemukakan ide-ide pengembangan pariwisata suatu destinasi (Araujo dan Bramwell, 1999; Bramwell dan Lane, 2000; Hall dan Page, 2006; Pansiria, 2013; Parker, 2000; Selin, 2000; Selin dan Chavez, 1995).

Suatu destinasi mungkin saja mengharapkan mampu memenangkan dunia persaingan dalam menarik wisatawan berkunjung ke destinasi wisata. Ketika destinasi ini mampu menjadi perhatian wisatawan, maka peluang untuk menarik investor untuk terlibat dalam aktifitas pariwisata sangat terbuka. Peluang pengembangan ekonomi dari sektor pariwisata menjadi besar karena stakeholder mengharapkan keuntungan atau kemanfaatan dari pengembangan pariwisata dan usaha pariwisata. Karena itu, kemitraan menjadi langkah awal dalam memberikan kesempatan kepada berbagai kelompok masyarakat untuk berpartisipasi dalam pengembangan pariwisata (Bramwell, 2004; Veal, 2002).

Sejak Indonesia menerapkan sistem otonomi daerah, maka tuntutan dan aktifitas yang berkaitan dengan kemitraan terutama di bidang pariwisata dan hospitaliti semakin 
terbuka. Dalam otonomi daerah, setiap wilayah atau destinasi wisata memiliki hak ataupun kesempatan untuk mengembangkan daerah (Brodjonegoro dan Asanuma, 2000; Duncan, 2007), termasuk mengembangkan destinasi dan daya tarik wisata di wilayah otonom. Otonomi daerah ini memberikan konsekuensi akan terbatasnya wewenang ataupun peran pemerintah pusat dalam melakukan upaya pengelolaan dan pengembangan pariwisata daerah.

Sebaliknya, daerah membutuhkan bantuan dalam mengelola aset daerah khususnya yang berkaitan dengan pariwisata. Kondisi ini menjadi isyarat bahwa kemitraan harus dibangun tidak hanya dengan berbagai tingkatan pemerintah, tetapi juga organisasi kepariwisataan di suatu daerah. Kemitraan ini akan memberikan kemudahan bagi pemerintah daerah dan pusat dalam menjalankan rencana dan kebijakan pengembangan pariwisata nasional dan daerah.

Uhlik (1995:14) mengemukakan bahwa kemitraan (partnership) adalah "an on-going arrangement between two or more partis, based upon satisfying specifically identified mutually needs (and) such partnerships are characterised by durability over time, inclusiveness, cooperation and flexibility". Kemitraan diartikan sebagai serangkaian bentuk atau struktur rencana dan aktifitas yang berkelanjutan antara dua atau lebih pihak dimana keduanya saling mengidentifikasi, mendukung dan memenuhi kebutuhan satu sama lain.
Kemitraan ditunjukkan dengan adanya periode waktu, keterlibatan, kerjasama serta fleksibilitas dalam mencapai tujuan. Kemitraan harus mencerminkan pencapaian keberlanjutan dan pencapaian tujuan yang direncanakan, disusun, diimplementasikan dan dicapai secara bersama-sama.

Kemitraan terkadang dikaitkan dengan istilah kolaborasi. Bramwell dan Lane (2000:4) mengemukakan bahwa "collaboration involves relationships between stakeholders when those parties interact with each other in relation to a common issue or 'problem domain". Kolaborasi melibatkan hubungan antara berbagai stakeholder dimana mereka melakukan proses interaksi satu sama lain untuk mencari ataupun melakukan hal-hal dalam mengatasi isu-isu ataupun masalah yang sedang menjadi perhatian kedua belah pihak.

Dilihat dari defenisi di atas, dapat dikemukakan bahwa kemitraan dan kolaborasi memiliki makna yang sama yakni keterlibatan individu atau kelompok dan melakukan kerjasama. Untuk tujuan penulisan karya tulis ini, penulis berpendapat bahwa kedua istilah tersebut pada dasarnya sama. Keduanya merupakan aspek penting yang harus dipertimbangkan dalam perencanaan pariwisata (Aas, Ladkin dan Fletcher, 2005; Bramwell dan Lane, 2000; Jamal dan Stronza, 2009; Jamal dan Getz, 1995).

Buckley (2010) berpendapat bahwa kemitraan merupakan bentuk pengelolaan daya tarik wisata yang terintegrasi (integrative management). Integrasi ini akan melibatkan beberapa 
pihak seperti industri akomodasi, perjalanan dan transportasi, pemerhati dan pecinta lingkungan dan budaya, institusi pendidikan, organisasi nonpemerintah dan nirlaba (non-profit organization), pemerintah serta masyarakat (Eagles, 2009; Fyall, Garrod, dan Leask, 2003).

\section{Bentuk-Bentuk Kemitraan Bidang Pariwisata dan Industri Hospitaliti} Sebagai sebuah pendekatan, kemitraan mungkin telah diimplementasikan oleh banyak organisasi ataupun lembaga yang berkaitan dengan pariwisata dan industri hospitaliti. Bramwell dan Lane (2000) mengemukakan beberapa bentuk atau istilah-istilah yang relevan dengan kemitraan yakni koalisi (coalition), forum (forums), aliansi (alliances), dan kemitraan publik dan swasta (public-private partnership). Dilihat dari istilah yang digunakan, koalisi, forum ataupun aliansi mungkin memiliki kesamaan dalam hal defenisi.

Keterlibatan manusia dalam suatu kelompok atau organisasi apakah dalam bentuk forum, koalisi, ataupun aliansi menunjukkan bahwa kemitraan berarti sekumpulan individu yang dengan latar belakang berbeda berkumpul dalam suatu wadah yakni koalisi, forum ataupun aliansi. Ketiga istilah ini selayaknya dibedakan dengan istilah organisasi yang di dalamnya juga terdapat individu yang bekerja untuk mencapai tujuan. Di Indonesia, terdapat beragam contoh koalisi, forum ataupun aliansi yang dibentuk oleh masyarakat untuk menyuarakan ataupun mencapai tujuan tertentu. Keterlibatan masyarakat (dengan latar belakang yang berbeda) di dalamnya menjadi ciri khas dari bentuk kemitraan ini.

Menurut Mason (2003), kemitraan dapat bersifat informal dan formal, kemitraan yang terstruktur, kemitraan yang bersifat khusus serta kemitraan yang bersifat lepas atau fleksibel. Terdapat kesamaan yang mendasar antara kemitraan yang terstruktur dan kemitraan formal. Terstruktur diartikan sebagai adanya ikatan kerjasama atau kemitraan antara satu institusi dengan institusi lainnya. Mereka diikat oleh suatu memorandum kerjasama yang mengatur dan menuntun langkah-langkah dan strategi yang perlu dilakukan untuk mencapai tujuan kerjasama.

Kemitraan formal juga memiliki panduan dalam mengimplementasikan bentuk nyata kemitraan. Namun, strukturisasi kemitraan yang terdiri dari posisi dan tugas masing-masing individu atau kelompok yang terlibat dalam kemitraan tersebut mungkin membedakan kedua bentuk kemitraan ini. Kedua bentuk kemitraan tersebut pada dasarnya dibangun untuk mencapai tujuan bersama kedua pihak yang melakukan kerjasama.

Kemitraan yang bersifat fleksibel juga memiliki kesamaan dengan kemitraan informal. Dalam mencapai tujuan, suatu institusi harus mampu melihat peluang-peluang pengembangan dan kondisi kekinian (termasuk perubahan yang mungkin muncul dalam suatu periode) dalam suatu destinasi. Program kerja yang dijalankan harus mampu menyesuaikan dengan kondisi sosial budaya dan politik yang terjadi. 
Meskipun sudah terdapat rencana program atau aktifitas yang akan dijalankan, fleksibilitas akan tetap diperhatikan dengan tidak meninggalkan esensi atau tujuan kemitraan.

Kemitraan informal terkadang dilaksanakan dengan melalui kesepakatan bersama dan pada suatu waktu atau periode tertentu. Dalam hal ini, ketika suatu institusi akan mengadakan program yang berkaitan dengan pariwisata (misalnya seminar pariwisata, kegiatan pameran, dll.), maka terdapat peluang melibatkan perusahaan-perusahaan ataupun kelompok masyarakat dalam bentuk sponsorship dan dukungan pelaksanaan kegiatan. Partisipasi mereka pada dasarnya dapat diartikan sebagai bentuk kemitraan antara berbagai stakeholder.

Kemitraan khusus dapat diartikan sebagai bentuk kerjasama yang dilakukan di bidang-bidang tertentu. Kemitraan di bidang pariwisata misalnya, dapat dilaksanakan dengan memfokuskan pada satu aspek. Pengembangan sumber daya manusia bagi aparatur atau pegawai pemerintah bidang pariwisata merupakan bentuk kemitraan yang melibatkan berbagai unsur termasuk keikutsertaan pihak luar (swasta) dalam memfasilitasi kegiatan tersebut. Dukungan organisasi atau lembaga tertentu terhadap event pariwisata yang dilaksanakan oleh pemerintah (maupun swasta) juga merupakan bentuk kemitraan pihak luar.

Bentuk kemitraan yang paling nampak dalam kegiatan atau pengembangan pariwisata adalah kemitraan antara sektor publik dan swasta. Sebagai contoh, pemerintah melakukan kemitraan dengan industri pariwisata (misalnya jasa perjalanan wisata) dalam melakukan program pengembangan pariwisata. Bentuk kegiatan dalam kemitraan ini tentunya disesuaikan dengan tujuan dan target kegiatan yang diharapkan, misalnya kegiatan pengembangan sumber daya manusia, dll.

Dalam konteks internasional, kemitraan antara Indonesia dan negara-negara di dunia (khususnya Asia) adalah bentuk komitmen Indonesia dalam mengajak dunia internasional bekerjasama di bidang pariwisata. Wong, Mistillis dan Dwyer (2010) mengemukakan bahwa perjanjian bilateral dan kerjasama antara Indonesia dengan negara-negara Asean (misalnya BIMP-EAGA, Brunei Darussalam-Indonesia-Malaysia

Philippines East ASEAN Growth Area) adalah contoh kemitraan yang dibangun untuk memajukan pariwisata Indonesia secara khusus dan stabilitas Asean secara umum. Wong, Mistillis dan Dwyer menyarankan bahwa negara-negara di dunia khususnya mereka yang berkedudukan sebagai pembuat kebijakan (policy maker) agar meningkatkan kemitraan dengan negara lain.

\section{Strategi Kemitraan Pengembangan Pariwisata dan Industri Hospitaliti}

Salah satu strategi atau kegiatan kemitraan yang berkaitan dengan pariwisata adalah kerjasama antara satu organisasi atau institusi dengan institusi lainnya. Sebagai contoh, 
kemitraan antara institusi pendidikan tinggi bidang pariwisata dan hospitaliti dengan organisasi non-pemerintah yang bertujuan untuk memfasilitasi pengembangan destinasi wisata di Indonesia yang dilakukan dengan berbagai aktifitas. Kegiatan dalam bentuk workshop dan seminar bidang kepariwisataan dengan tujuan pengembangan keilmuan, pengetahuan dan pengalaman tenaga pengajar institusi pendidikan tinggi bidang pariwisata dan hospitaliti yang difasilitasi oleh organisasi nonpemerintah merupakan salah satu bentuk nyata implementasi kemitraan. Kemitraan dalam hal ini menjadi strategi utama dalam meningkatkan sumber daya manusia pencetak generasi yang diharapkan mampu menjadi pioneer pengembangan pariwisata Indonesia.

Di bidang pelestarian budaya dan pengembangan pariwisata budaya, masyarakat yang secara khusus bekerja di bidang budaya dapat difasilitasi mengikuti kegiatan pembimbingan pelestarian dan pemahaman pariwisata budaya. Menurut Jordan dan Duval (2009), pengembangan kapasitas pengalaman dan pengetahuan pengelola museum, pegawai arsip daerah, pegawai perpustakaan, pecinta dan pemerhati budaya (kelompok budaya) serta pegawai pemerintah dan swasta bidang kebudayaan adalah mereka yang seharusnya memperoleh kegiatan workshop pelestarian budaya. Kegiatan ini mungkin saja tidak dapat berjalan dengan maksimal tanpa adanya kemitraan antara satu institusi dengan institusi lainnya.
Ragam destinasi wisata di Indonesia menghendaki kerjasama dalam bentuk kemitraan antara satu destinasi dengan destinasi lainnya. Pemerintah daerah (dalam hal ini pemerintah kabupaten dan kota) diharapkan menjalin kemitraan dengan pemerintah daerah lainnya. Suatu kabupaten atau kota tidak dapat mengandalkan potensi kedaerahan yang dimiliki tanpa didukung oleh daerah lain sebagai jembatan menuju dan dari suatu destinasi wisata.

Dari segi implementasi, pemerintah daerah dapat melakukan kerjasama (kemitraan) dalam bentuk saling memahami (mutual understanding) akan pentingnya mempromosikan aset atau potensi daerah untuk tujuan pariwisata yan berkelanjutan. Karenanya, Dinas pariwisata daerah seharusnya menjadikan daerah lain sebagai mitra, bukan sebagai pesaing (competitor). Terkadang, suatu daerah mungkin sudah maju dalam hal jumlah wisatawan yang berkunjung, sementara daerah lain yang menjadi tetangga sangat jauh tertinggal di bidang paiwisata. Kemitraan akan memberikan kesempatan bagi daerah lain untuk mengembangkan pariwisata dengan menjadikan destinasi yang sukses sebagai motivator atau jembatan mengembangkan pariwisata.

Di bidang hospitaliti, kerjasama antara perusahaan dengan perusahaan lain merupakan salah satu strategi kemitraan. Hsu dan Power (2000) memberikan contoh kemitraan strategis yang dilakukan oleh hotel Radisson dan hotel SAS di Eropa. Kemitraan yang dilakukan kedua hotel 
ini adalah dalam bidang pemasaran dengan menggabungkan hotel mereka menjadi Radisson SAS hotels. Strategi kemitraan seperti ini dapat menjadi jembatan membangun kepercayaan publik terhadap eksistensi suatu perusahaan pelayanan jasa di bidang hospitaliti.

Industri katering (catering industry) yang fokus utamanya adalah memberikan pelayanan makanan dan minuman serta usaha kecil atau menengah di bidang laundry juga dapat melakukan kemitraan dengan industri atau usaha akomodasi. Kemitraan seperti ini layak diterapkan dalam upaya memberikan pelayanan yang maksimal kepada wisatawan. Kemitraan seperti ini sangat tepat diterapkan di daerah-daerah dimana usaha akomodasi terkadang masih memiliki keterbatasan fasilitas atau pendukung dalam pelayanan kepada tamu. Kemitraan memungkinkan suatu usaha pariwisata memaksimalkan pelayanan kepada pelanggan.

Strategi kemitraan yang paling nampak saat ini adalah industri penerbangan yang menawarkan rute perjalanan kepada wisatawan di seluruh destinasi di dunia. Dalam beberapa hal, suatu perusahaan penerbangan tidak memiliki rute perjalanan dari dan menuju ke suatu destinasi di dunia. Dengan kemitraan yang dilakukan antara perusahaan penerbangan, seorang wisatawan dapat mencapai destinasi wisata di dunia. Jadi, tidak heran jika seorang wisatawan mengadakan perjalanan dengan menggunakan dua atau lebih jenis perusahaan penerbangan yang berbeda. Kemitraan seperti ini telah memudahkan pengguna jasa penerbangan untuk menentukan dan memilih penerbangan yang mereka inginkan.

Dalam mengimplementasikan kemitraan, terdapat tiga pendekatan atau tahap yang dapat dijalankan oleh mereka yang terlibat dalam kemitraan yakni menelaah atau memahami masalah (problem-setting), memahami, menganalisis atau menentukan kebijakan bersama (direction setting) dan tahap implementasi (structuring concern) (Selin, 1999; Parker, 2000). Pada tahap problem-setting, kedua pihak diharapkan menganalisis secara seksama dan mendalam hal-hal apa yang menjadi kebutuhan bersama dan tantangan atau hambatan yang mungkin dihadapi ketika akan melakukan kerjasama atau kemitraan. Tentunya, identifikasi dan analisis ini dilakukan secara bersama-sama dan saling pengertian dengan prinsip bahwa identifikasi ini semata-mata bertujuan agar program yang dijalankan betul-betul memberikan manfaat kepada kedua pihak.

Pada tahap direction setting, telah disepakati hal-hal apa yang akan dilakukan dalam rangka kemitraan tersebut. Tahap ini lebih mengarah pada teknis atau kegiatan yang akan dilakukan dalam menghadapi dan mengatasi masalah yang telah diidentifikasi bersama. Pada tahap ini, telah dihasilkan struktur, rencana periode pelaksanaan kegiatan, serta hal-hal yang bersifat teknis agar program kerja dapat berjalan dengan baik. Pada tahap structuring concern, pihak-pihak yang terkait telah mengimplementasikan rencana 
kegiatan yang telah disepakati sebelumnya. Pada tahap ini pula, evaluasi dan monitoring menjadi bagian yang tak terpisahkan agar program kerja yang dijalankan dapat lebih ditingkatkan dari segi kualitas.

\section{Manfaat Kemitraan Dalam Pengembangan Pariwisata dan Industri Hospitaliti}

Pengembangan pariwisata yang ideal menuntut kemitraan diantara kelompok masyarakat yang ada. Hal ini mengisyaratkan bahwa kemitraan memiliki keuntungan atau manfaat dalam mencapai tujuan pengembangan pariwisata. Pertama, keterlibatan stakeholder yang beragam dalam perencanaan pariwisata dan penentuan kebijakan tentu dilakukan melalui proses diskusi. Dalam proses ini tentunya nilai-nilai kesepahaman diantara stakeholder yang ada harus dijunjung tinggi. Dalam hal ini, nilainilai demokratis dalam pengambilan keputusan dan kebijakan terimplementasikan secara nyata. Kebijakan pariwisata diharapkan merupakan hasil keputusan bersama oleh stakeholder melalui proses yang demokratis. Dari proses ini masyarakat terlibat secara bersama-sama mengimplementasikan kebijakan pariwisata yang telah diambil.

Kedua, kemitraan memberikan peluang bagi setiap stakeholder untuk mempelajari keunggulan dalam kegiatan kemitraan yang dilakukan. Dalam hal realitas, Dinas pariwisata daerah mungkin melakukan kegiatan pariwisata yang merupakan hasil dari kemitraan yang dibangun bersama dengan lembaga non-pemerintah yang bekerja di bidang pengembangan pariwisata. Dari kegiatan ini pemerintah akan belajar bagaimana organisasi non-pemerintah tersebut bekerja. Sebaliknya, proses belajar juga terjadi ketika organisasi nonpemerintah tersebut memahami proses birokrasi dan administrasi terutama dalam hal melaksanakan program kerja bidang kepariwisataan.

Ketiga, kemitraan membantu stakeholder dalam mengambil keputusan terutama jika pengembangan pariwisata dan industri hospitaliti harus menyesuaikan dengan perubahan kondisi di sebuah destinasi. Sebagai contoh, pemerintah (baik pusat maupun daerah) yang akan memberikan pelatihan ataupun bimbingan kepariwisataan untuk masyarakat, harus mampu menyesuaikan dengan perubahan ataupun kondisi yang ada di masyarakat. Kemitraan antara pemerintah dan masyarakat akan membantu mensukseskan pelaksanaan program kerja tersebut meskipun mungkin terdapat kondisi atau situasi yang mengharuskan penyesuaian waktu, metode ataupun langkahlangkah kegiatan pembimbingan dan pelatihan.

Manfaat lain dari kemitraan adalah bahwa kerjasama dapat mencegah terjadinya konflik yang merugikan antara berbagai kelompok yang berbeda (Bramwell dan Lane, 2000; Mason, 2003). Tidak dapat dihindari bahwa ketidakseimbangan kemanfaatan yang didapatkan oleh setiap individu atau kelompok dalam suatu kemitraan dapat saja terjadi. Terdapat individu yang mungkin saja 
memperoleh kesempatan yang besar dalam suatu aktifitas. Sementara, keinginan individu-individu lainnya untuk terlibat dalam suatu proyek menjadi terbatas karena dominasi kelompok atau individu tertentu. Konflik seperti ini biasanya terjadi dalam suatu internal institusi, namun konflik (misalnya kesalahpahaman) dapat pula terjadi diantara organisasi yang berbeda. Kemitraan akan membantu suatu institusi untuk saling memahami (mutual understanding) akan kebutuhan individu ataupun lembaga yang terlibat kerjasama. Dalam hal ini, sinergi yang baik antara berbagai stakeholder akan tercipta melalui kemitraan yang terjalin dengan baik.

Selanjutnya, kemitraan yang dilakukan oleh industri hospitaliti sebagaimana yang diuraikan pada bagian sebelumnya memberikan manfaat dalam hal peningkatan penjualan pelayanan jasa. Dengan kemitraan, perusahaan dapat meraih atau memperoleh pelanggan baru (new customer) dan meningkatkan pelayanan jasa bagi customer (Hsu dan Power, 2002). Selain itu, kemitraan dapat mengurangi biaya yang dibutuhkan untuk memasarkan suatu produk usaha pariwisata. Sebagai contoh, usaha pelayanan makanan dan minuman dapat melakukan kerjasama dengan usaha perjalanan wisata. Bagi pengelola usaha makanan dan minuman, agen perjalanan wisata dapat menjadi ujung tombak pemberian informasi kepada customer ataupun wisatawan mengenai eksistensi usaha makanan dan minuman. Sesungguhnya, pemandu wisata (guide) membawa tamu ke suatu usaha makanan dan minuman. Kesan positif yang diperoleh tamu akan berdampak pada keberlanjutan dan keuntungan usaha makanan dan minuman tersebut. Karena itu, kemitraan akan meminimalkan biaya promosi yang harus dikeluarkan oleh suatu usaha pariwisata.

Dunia persaingan usaha di bidang hospitaliti tak terhindarkan terutama jika di suatu wilayah jumlah usaha pariwisata yang sama bermunculan. Kemitraan menjadi salah satu alternatif untuk mengantisipasi persaingan tersebut. Kemitraan menjadikan suatu usaha pariwisata memikirkan upaya kreatif secara bersama-sama (kolektif) dengan mitra kerja untuk menerapkan pendekatan ataupun strategi yang dapat diterapkan untuk memenangkan dunia persaingan. Dengan dukungan dari mitra kerja, suatu usaha ataupun perusahaan dapat memaksimalkan pendapatan, tentunya didasarkan pada prinsip saling menguntungkan.

\section{KESIMPULAN}

Upaya untuk melibatkan para pemangku kepentingan (stakeholder) sebagai pemain utama (key players) dalam pengembangan pariwisata dapat dilakukan melalui program kemitraan. Perencanaan pariwisata, pengelolaan destinasi dan daya tarik wisata serta pengembangan industri hospitaliti adalah aspek yang membutuhkan kemitraan karena melibatkan pemikiran, pengetahuan, pengalaman dari masyarakat dari berbagai latar belakang yang berbeda. Diskusi (ataupun dialog) dan kesepakatan 
bersama dari para stakeholder dalam merencanakan dan mengembangkan pariwisata dan industri hospitaliti menjadi kekuatan utama kemitraan.

Kemitraan dapat dilakukan antara suatu institusi atau perusahaan dengan institusi atau perusahaan lain. Terdapat beberapa pendekatan dalam menerapkan kemitraan misalnya, kemitraan yang bersifat formal dan informal, terstruktur maupun fleksibel. Dalam perkembangannya, suatu institusi atau perusahaan atau masyarakat dapat membentuk kemitraan yamg berbentuk koalisi, forum, aliansi, kemitraan publikswasta yang pada prinsipnya dilakukan untuk mengidentifikasi dan memenuhi kebutuhan bersama dengan prinsip saling menguntungkan.

Dari beberapa contoh uraian manfaat kemitraan, dapat disimpulkan bahwa kemitraan dapat menjadi suatu strategi mengembangkan pariwisata di suatu wilayah serta mendorong produktifitas perusahaan khususnya industri hospitaliti. Karena itu, sudah selayaknya stakeholder pariwisata mengimplementasikan kemitraan baik dalam perencanaan maupun dalam implementasi program kerja bidang pengelolaan destinasi atau daya tarik wisata maupun usaha pariwisata.

\section{DAFTAR PUSTAKA}

Aas, Christina., Ladkin, Adele., dan Fletcher, John. 2005. Stakeholder collaboration and heritage management. Dalam Timothy, Dallen. J. Editor. Managing heritage and cultural tourism resources: Critical essays, Vol. 1. Farnham: Ashgate, Hal. 1-22.

Ardahaey, Fateme. Tohidy. 2011. Economic impacts of tourism. International Journal of Business and Management, Vol. 6 No. 8, Hal. 206-215.

Archer, Brian., Cooper, Chris., dan Ruhanen, Lisa. 2005. The positive and negative impacts of tourism. Dalam Theobald, William. F. Editor. Global tourism, Edisi ketiga. Amsterdam: Elsevier. Hal. 79-102.

Bramwell, Bill. 2004. Partnerships, participation, and social science research in tourism planning. Dalam Lew, Alan. A., Hall, C. Michael., dan Williams, Allan. M. Editor. A companion to tourism Malden: Blackwell, Hal. 541-554.

Brodjonegoro, Bambang., dan Asanuma, Shinji. 2000. Regional autonomy and fiscal decentralization in democratic Indonesia. Hitotsubashi Journal of Economics, Vol. 41, Hal. 111-122.

Buckley, Ralf. 2010. Conservation tourism. Wallingford: CABI.

Caffyn, Alison. 2000. Developing sustainable tourism in the Trossachs, Scotland. Dalam Richards, Greg., dan Hall, Derek. Editor. Tourism and sustainable community development. London: Routledge, Hal. 83-100.

Cooper, Chris., dan Hall, C. Michael. 2008. Contemporary tourism: an international approach. Oxford: Elsevier.

Dahles, Heidi. 2000. Tourism, small enterprises and community development. Dalam Dalam 
Richards, Greg., dan Hall, Derek. Editor. Tourism and sustainable community development. London: Routledge, Hal. 154-169.

De Araujo, L. Medeiros., dan Bramwell, Bill. 1999. Stakeholder assessment and collaborative tourism planning: The case of Brazil's Costa Dourada Project. Journalof Sustainable Tourism, Vol. 7, No. 3 \& 4, Hal. 356-378.

Duncan, Christopher. R. 2007. Mixed outcomes: the impact of regional autonomy and decentralization on indigenous ethnic minorities in Indonesia. Development and Change, Vol. 38, No. 4, Hal. 711733.

Eagles, P.F.J. 2009. Governance of recreation and tourism partnerships in parks and protected areas. Journal of Sustainable Tourism Vol. 17, Hal. 231-248.

Fyall, Alan., dan Garrod, Brian. 2005. From competition to collaboration in the tourism industry. Dalam Theobald, William. F. Editor. Global tourism. Edisi ketiga. Amsterdam: Elsevier. Hal. 52-74,

Fyall, Alan., Garrod, Brian., dan Leask, Anna. 2003. Managing visitor attractions: New directions. Oxford: ButterworthHeinemann.

Getz, Donald., dan Timur, Seldjan. 2005. Stakeholder involvement in sustainable tourism: Balancing the voices. Dalam Theobald, William. F. Editor. Global tourism. Edisi ketiga. Amsterdam: Elsevier. Hal. 230-247.
Hall, C. Michael., dan Page, Stephen. J. 2006. The geography of tourism and recreation. London: Routledge.

Hsu, Cathy. H., dan Powers, Tom. 2002. Marketing hospitality: John Wiley \& Sons.

Jamal, Tazim., dan Stronza, Amanda. 2009. Collaboration theory and tourism practice in protected areas: stakeholders, structuring and sustainability. Journal of Sustainable Tourism, Vol. 17, No. 2, Hal. 169-189.

Jamal, T., dan Getz, D. 1995. Collaboration theory and community tourism planning. Annals of Tourism Research, Vol. 22, Hal. 186-204.

Jordan, Leslie-Ann., dan Duval, David. T. 2009. Heritage management and tourism in the Carribean. Dalam Timothy, Dallen. J., dan Nyaupane, Gyan. P. Editor. Cultural heritage and tourism in the developing world: a regional perspective. London: Routledge. Hal. 186-208.

Mason, Peter. 2003. Tourism impacts, planning and management. Burlington: ButterworthHeinemann.

Pansiria, Jaloni. 2013. Collaboration and partnership in tourism: The experience of Botswana. Tourism Planning \& Development, Vol. 10, No. 1, Hal. 64-84.

Parker, Steven. 2000. Collaboration on tourism policy making: Environmental and commercial sustainability on Bonaire, MA. Dalam Bramwell, Bill., dan Lane, Bernard. Editor. Tourism 
collaboration and partnerships:

Politics, practice and sustainability. Clevedon: Channel View publications. Hal. 78-97.

Selin, Steve. 2000. Developing a typology of sustainable tourism partnerships. Dalam Bramwell, Bill., dan Lane, Bernard. Editor. Tourism collaboration and partnerships: Politics, practice and sustainability. Clevedon: Channel View Publications. Hal. 129-142.

Selin, Steve., dan Chavez, Debbie. 1995. Developing an evolutionary tourism partnership model. Annals of Tourism Research, 22, 844-856.

Stronza, Amanda. 2008. Partnership for tourism development. Dalam Moscardo, Gianna. Editor. Building community capacity for tourism development. Wallingford: CABI. Hal. 101-115.

Tuohino, Anja., dan Konu, Henna. 2014. Local stakeholders' view about destination management: who are leading tourism development? Tourism Review, Vol. 69, No. 3, Hal. 202-215.

Uhlik, Kim. S. 1995. Partnerships: step by step: a practical model of partnership formation. Journal of
Parkand Recrdministration, Vol. 143, Hal. 13-24.

Veal, Anthony. J. 2002. Leisure and tourism policy and planning. Wallingford: CABI.

Wearing, Stephen., dan Neil, John. 2009. Ecotourism:impacts, potentials and possibilities. Oxford: Elsevier.

Wong, Emma. P. Y., Mistilis, Nina., dan Dwyer, Larry. 2010. Understanding ASEAN tourism collaboration-the preconditions and policy framework formulation. International Journal of Tourism Research, Vol. 12, Hal. 291-302. 